\title{
Metamorphic conditions during formation of a metapelitic sillimanite-garnet gneiss from Clemence Massif, Prince Charles Mountains, East Antarctica
}

\author{
A. F. Corvino, S. D. Boger, and C. J. L. Wilson \\ School of Earth Sciences, The University of Melbourne, Victoria, 3010, Australia
}

\begin{abstract}
The pressure $(P)$ and temperature $(T)$ conditions during metamorphism of a metapelitic sillimanite-garnet gneiss from Clemence Massif, Antarctic Prince Charles Mountains, are estimated using mineral abundance information and petrogenetic $P-T$ pseudosections computed in the chemical system $\mathrm{MnO}-\mathrm{N}_{2} \mathrm{O}-\mathrm{CaO}-\mathrm{K}_{2} \mathrm{O}-\mathrm{FeO}_{-} \mathrm{MgO}-\mathrm{Al}_{2} \mathrm{O}{ }_{3}-$ $\mathrm{SiO}_{2}-\mathrm{H}_{2} \mathrm{O}-\mathrm{TiO}_{2}-\mathrm{Fe}_{2} \mathrm{O}_{3}(\mathrm{MnNCKFMASHTO})$. Calculated mineral equilibria for the appropriate bulk composition predict that the observed assemblage, of K-feldspar-garnet-quartz-sillimanite-biotite-ilmenite-rutile, stabilised at approximately $8-9 \mathrm{kbar}$ and $760-790^{\circ} \mathrm{C}$. Reaction microstructures are rare, but the preservation of relic spinel inclusions in garnet indicates an earlier low- $P$, high- $T$ component and possible anticlockwise path.
\end{abstract}

Citation: Corvino A. F., S. D. Boger, and C. J. L. Wilson (2007), Metamorphic conditions during formation of metapelitic sillimanite-garnet gneiss from Clemence Massif, Prince Charles Mountains, East Antarctica, in Antarctica: A Keystone in a Changing World - Online Proceedings of the $10^{\text {th }}$ ISAES, edited by A.K. Cooper and C.R. Raymond et al., USGS Open-File Report 2007-1047, Short Research Paper 062, 9 p.; doi:10.3133/of2007-1047.srp062

\section{Introduction}

In the central Antarctic Prince Charles Mountains (PCM), between latitudes $72^{\circ} \mathrm{S}$ and $72^{\circ} 30^{\prime} \mathrm{S}$, the Clemence Massif (Fig. 1) forms the largest exposure of a predominantly Late Proterozoic/Early Palaeozoic age crustal belt. This belt also includes Mounts Johns and Izabelle, Shaw Massif, Bosse and Ely Nunataks and Lawrence Hills, that have been previously correlated with Clemence Massif on the basis of compatible $\sim 1000 \mathrm{Ma}$ $\mathrm{Rb}-\mathrm{Sr}$ whole-rock ages for felsic gneisses, similar structural styles and lack of intrusive mafic dykes (Tingey et al., 1981; Mikhalsky et al., 2001).

Recent U-Pb zircon dating by Corvino et al. (2005) indicates that the Clemence Massif consists of 1060 million year old felsic orthogneiss structurally overlain by, and locally interleaved with, paragneisses of uncertain age all reworked under granulite-facies conditions at $\sim 1000$ and/or 500 million years ago. Importantly, gneisses from this massif preserve evidence for coexistence of both $\sim 1000 \mathrm{Ma}$ and $\sim 500 \mathrm{Ma}$ dates in single zircons, although it is unclear which of these dates accurately reflects the principal metamorphic event. At this point, granulite-facies reworking at Clemence Massif may be related to either of the $\sim 1000 \mathrm{Ma}$ (Grenvillian) or $\sim 500 \mathrm{Ma}$ (Pan-African) tectonic events that are widely recognised in East Antarctica (amongst others Krynauw, 1996 and Yoshida et al., 2003). Furthermore, the possible superimposition of these two events throughout the central region of the PCM is an unresolved matter of concern.

In this paper, we identify the physical conditions of metamorphism for Clemence Massif on the basis of phase relations recorded in a rare metapelitic gneiss, with the aim of further illuminating the relative importance of the $\sim 1000 \mathrm{Ma}$ and $\sim 500 \mathrm{Ma}$ events at this location. Our approach utilises petrogenetic pseudosections, along with a knowledge of mineral abundances and the relevant bulk composition, following closely the method and logic of Stüwe and Powell (1995).

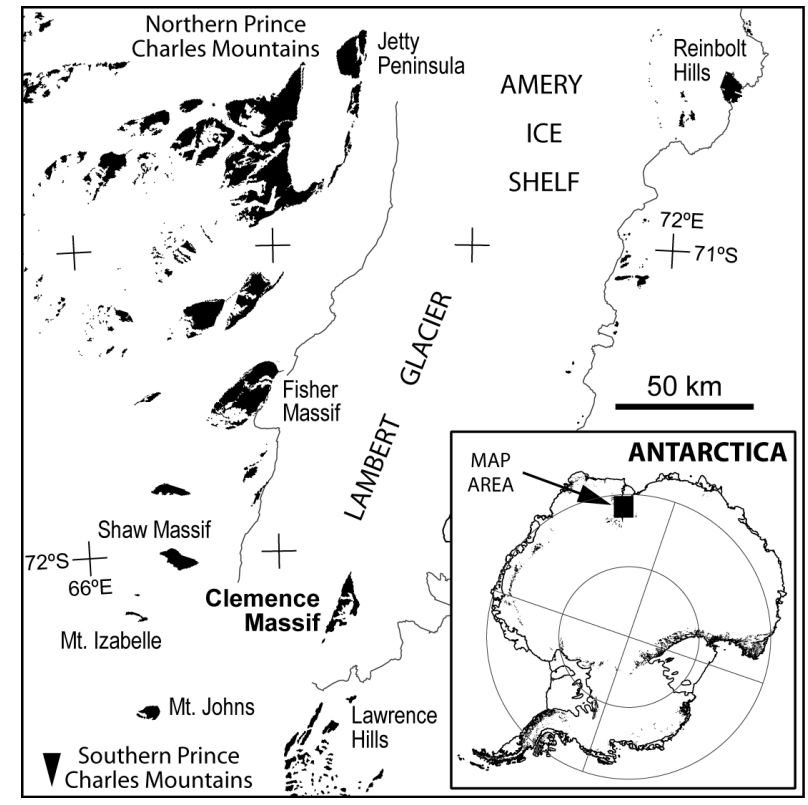

Figure 1. Map showing the location of Clemence Massif in the Prince Charles Mountains, Antarctica.

\section{Petrography and mineral chemistry}

The sample in this study (Fig. 2) was collected from a metre-thick layer of metapelitic gneiss located on the east side of Clemence Massif, at latitude $72^{\circ} 11{ }^{\prime} 55^{\prime \prime} \mathrm{S}$ and longitude $62^{\circ} 49^{\prime} 26^{\prime \prime} \mathrm{E}$. It has a fabric formed by layers of preferably oriented sillimanite that anastomose about garnet poikiloblasts and alternate with perthite-rich leucosome domains ( $\sim \mathrm{mm}$ thick), which are often tapered and discontinuous. The sillimanite is oriented subparallel to the principal foliation at Clemence Massif that is typically defined by a gneissose and migmatitic layering with regular dip of $\sim 40^{\circ}$ towards the southwest (McLeod, 1959; Tingey et al., 1981; Corvino et al., 2005).

The mineral assemblage consists of perthitic Kfeldspar (32 vol.\%), garnet (24 vol.\%), quartz (20 vol.\%), sillimanite (19 vol.\%), biotite (3 vol.\%) and ilmenite (2 vol.\%), along with minor rutile and relic spinel that 
together comprise $<0.3 \%$ of the rock volume (Table 1 ). Chemical data for the minerals are given in Appendix B (Tables B1 and B2).

$\mathrm{K}$-feldspar has a grain size of $500-1500 \mu \mathrm{m}$ and is mostly perthite comprising $\sim 82$ mol.\% orthoclase $(=100 \cdot \mathrm{K} / \mathrm{Ca}+\mathrm{Na}+\mathrm{K})$ and $\sim 18 \quad \mathrm{~mol} \%$ albite $(=100 \cdot \mathrm{Na} / \mathrm{Ca}+\mathrm{Na}+\mathrm{K})$, with $<1 \quad \mathrm{~mol} \%$ anorthite $(=100 \cdot \mathrm{Ca} / \mathrm{Ca}+\mathrm{Na}+\mathrm{K})$. Adjacent grain boundaries are straight, or cuspate-and-lobate where they are in contact with quartz which forms irregular shapes and fine blebtype growths $(25-250 \mu \mathrm{m})$. Both K-feldspar and quartz may be elongate and host fine sillimanite inclusions where they are associated with sillimanite masses. Incipient subgrains are evident in quartz.

Garnet is an almandine-pyrope (Fe-Mg) solid solution, with 71 mol.\% almandine $\left(=100 \cdot \mathrm{Fe}^{\mathrm{T}} / \mathrm{Fe}^{\mathrm{T}}+\mathrm{Mg}+\mathrm{Ca}+\mathrm{Mn}\right)$, and contains $<5 \mathrm{~mol} . \%$ total spessartine $\left(=100 \cdot \mathrm{Mn} / \mathrm{Fe}^{\mathrm{T}}+\mathrm{Mg}+\mathrm{Ca}+\mathrm{Mn}\right)$ and grossular $\left(=100 \cdot \mathrm{Ca} / \mathrm{Fe}^{\mathrm{T}}+\mathrm{Mg}+\mathrm{Ca}+\mathrm{Mn}\right)$. Significant compositional zoning is not evident. Most garnet forms irregular-toglobular, fractured poikiloblasts $(2-5 \mathrm{~mm}$ diameter $)$ with inclusions of quartz, ilmenite and biotite; the inclusion sizes are $<250 \mu \mathrm{m}$ and more rounded than their counterparts in the adjoining matrix. Inclusion trails are uncommon, but they do occur in a few remarkable garnets as shown in Figure 3a. The trails are oriented obliquely to the external fabric, as defined by sillimanite, and do not continue into it. This suggests that some garnet growth probably preceded development of the sillimanite-defined fabric (cf. Johnson and Vernon, 1995).

Sillimanite may be intergrown with garnet poikiloblast edges, but it mostly anastomoses around these. It occurs as fibrolitic masses and (relatively) large prismatic crystals, with lengths ranging from $50 \mu \mathrm{m}$ to $3000 \mu \mathrm{m}$, and length/width indices of about 10. Several of the largest sillimanite grains are gently kinked and show undulatory extinction. Some are conspicuously misaligned with respect to the main foliation, as shown in Figure $3 b$, and possibly reflect late growth.

Biotite is a phlogopite-annite solid solution with molar $\mathrm{Mg} / \mathrm{Fe}^{\mathrm{T}}+\mathrm{Mg}$ ratios of $0.52-0.73$. Titanium contents range from 0.37 to 0.71 atoms per 22 oxygens, decreasing in accordance with increasing $\mathrm{Mg} / \mathrm{Fe}^{\mathrm{T}}+\mathrm{Mg}$. The majority of biotite occurs as dispersed laths $<1 \mathrm{~mm}$ in contact with all matrix phases, or forms irregular late growths between sillimanite crystals and garnet fractures. Some biotite hosts sagenitic rutile as shown in Figure 3c. The rutile forms asterisk-shaped aggregates of acicular inclusions $<100 \mu \mathrm{m}$ in length and intersecting at angles of $\sim 60^{\circ}$ analogous to descriptions by Shau et al. (1991). Rutile is also present in the matrix and as inclusions within garnet.

Ilmenite is mostly pure $\mathrm{FeTiO}_{3}$ with only $0.01 \mathrm{Mn}$ apfu (per $6 \mathrm{O}$ ). Like biotite, it appears as rectangular shapes disseminated throughout the matrix or as irregular growths interspersed with sillimanite (Fig. 3b).

Spinel is primarily a hercynite-gahnite-spinel solid solution, with as much as 27 mol.\% gahnite $\left(=100 \cdot \mathrm{Zn} / \mathrm{Fe}^{\mathrm{T}}+\mathrm{Mg}+\mathrm{Zn}\right)$. It is absent from the matrix and occurs only within garnet porphyroblasts as relic blebshaped inclusions $<250 \mu \mathrm{m}$ (Fig. 3c).

All phases, excluding spinel, are assumed to have crystallised in local equilibrium. Notably absent phases are plagioclase and cordierite.

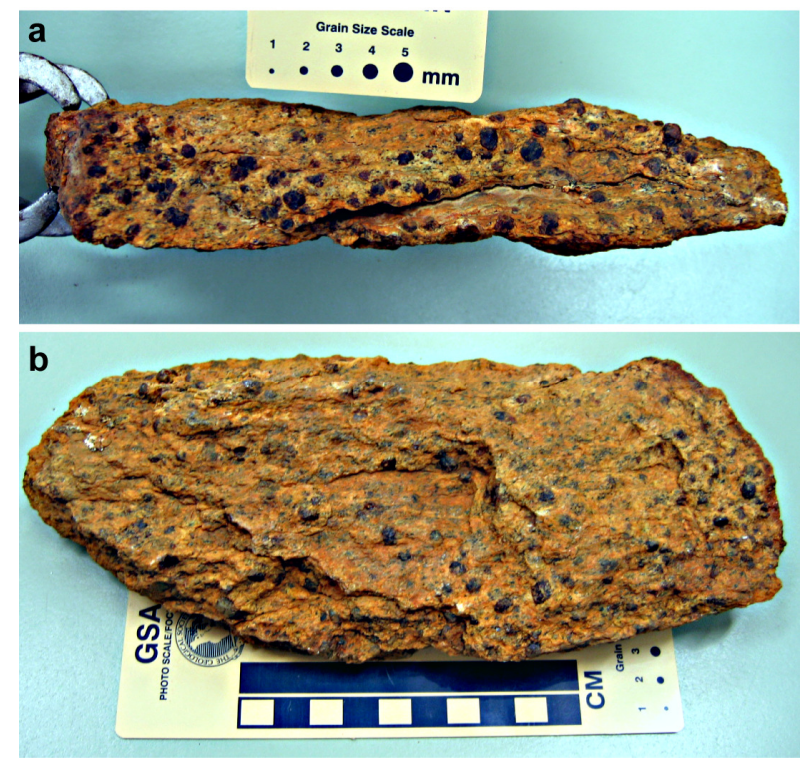

Figure 2. Photographs of the study sample. (a) Subparallel, and (b) oblique to the principal foliation. The porphyroblasts are garnet.

Table 1. Petrographic data for the metapelitic gneiss in this study. Point counts were made of two thin-sections (i and ii) using a graduated mechanical stage and sampling interval of $667 \mu \mathrm{m}$ (Glagolev-Chayes method, see Carver, 1971). Molar abundances of each phase were calculated by dividing vol.\% by molar volumes, and multiplying by the number of oxides per mineral formula (using the data given in Appendix A). The values are recalculated to $100 \%$.

\begin{tabular}{lcccccccc}
\hline & K-feldspar & quartz & sillimanite & garnet & ilmenite & biotite & rutile & Totals \\
\hline Point counts i & 439 & 295 & 266 & 195 & 24 & 27 & 4 & 1250 \\
Point counts ii & 372 & 201 & 199 & 409 & 19 & 49 & 1 & 1250 \\
i+ii & 811 & 496 & 465 & 604 & 43 & 76 & 5 & 2500 \\
Vol.\% (i+ii) & 32.4 & 19.8 & 18.6 & 24.2 & 1.7 & 3.0 & 0.2 & 100 \\
Mol. abundance \% & 26.2 & 19.2 & 16.4 & 32.5 & 2.4 & 3.1 & 0.2 & 100 \\
Wt.\% & 27.0 & 16.9 & 19.5 & 30.7 & 2.6 & 2.9 & 0.3 & 100 \\
\hline
\end{tabular}





Figure 3. Microphotographs. (a) Garnet poikiloblast with rare inclusion trail $\left(\mathrm{S}_{\mathrm{i}}\right)$ defined by an opaque phase, probably ilmenite, and sparse hercynite blebs indicated by arrows. Scale bar $\sim 2 \mathrm{~mm}$. (b) Aggregates of fibrolitic sillimanite and a few larger sillimanite crystals with lesser ilmenite and biotite. Scale bar $\sim 1 \mathrm{~mm}$. (c) Late biotite with sagenitic rutile (bi*). Scale bar $\sim 100 \mu \mathrm{m}$.

\section{Bulk chemical composition}

A first approximation of the bulk rock composition was made using mineral abundances (Table 1) and chemical data (Tables B1 and B2) following the petrographic method of Friedman (1960). The result is shown in Table 2. Ferric iron contents were considered in this calculation by assuming $\mathrm{Fe}^{3+} / \mathrm{Fe}^{\mathrm{T}}$ ratios of 0.08 for biotite (Guidotti and Dyar, 1991), and 0.05 for ilmenite based on example fractions from normal terrestrial rocks $\left(\sim 0.10\right.$, Deer et al., 1992) and $\mathrm{Fe}^{3+}$ depleted granulites $\left(\leq 0.01\right.$, Cesare et al., 2005). $\mathrm{Fe}^{3+}$ in garnet was assumed to be negligible (after Dyar et al., 2002).

An independent chemical analysis was also undertaken using the SPECTRO XLAB2000 X-ray Fluorescence Spectroscopy (XRF) facility at Macquarie University, Australia. Major oxide abundances, obtained for a 50 gram powder aliquot, are given in Table 2. In comparison to the petrographic based calculation, the XRF results show greater $\mathrm{Si}, \mathrm{K}$ and $\mathrm{Na}$ contents, and lesser $\mathrm{Al}, \mathrm{Fe}, \mathrm{Mg}$ and $\mathrm{Ti}$ contents, that suggests a slightly higher leucosome:melanosome ratio.

Overall, the metapelitic gneiss has relatively low molar $\mathrm{MgO} /(\mathrm{MgO}+\mathrm{FeO})$ value of 0.27 , which clearly reflects almandine abundance and composition (Table B1), and high $\mathrm{Al}_{2} \mathrm{O}_{3}$ content (cf. Sheraton, 1980). About half of the total $\mathrm{Al}_{2} \mathrm{O}_{3}(15.10$ mol.\%) occurs in sillimanite, with the remainder accounted for largely by garnet followed by $\mathrm{K}$-feldspar. K-feldspar is the main source of total $\mathrm{K}_{2} \mathrm{O}(3.18 \mathrm{~mol} . \%)$ and $\mathrm{Na}_{2} \mathrm{O}(0.93 \mathrm{~mol} . \%)$, and minor $\mathrm{CaO}(0.41 \mathrm{~mol} . \%)$ which is also included in garnet. Titania (1.03 mol.\%) is partitioned into ilmenite, biotite and rutile. The minor amount of $\mathrm{MnO}(0.11 \mathrm{~mol} . \%)$ must occur mainly in garnet and ilmenite based on microprobe analyses (Appendix B).

The estimated amount of $\mathrm{Fe}_{2} \mathrm{O}_{3}$ is 0.10 mol.\%. This value is considered to be realistic because biotite and ilmenite, likely $\mathrm{Fe}^{3+}$ bearing phases, constitute only a very small amount of the rock volume $(<5 \%)$. Assuming higher $\mathrm{Fe}^{3+} / \mathrm{Fe}^{\mathrm{T}}$ ratios of say 0.16 for biotite, and 0.10 for ilmenite, in the petrographic calculation increases the total $\mathrm{Fe}_{2} \mathrm{O}_{3}$ content to only $\sim 0.20 \mathrm{~mol} . \%$.

Since mostly anhydrous phases are preserved, the $\mathrm{H}_{2} \mathrm{O}$ content is undoubtedly low in accord with significant melt loss from the metapelite system (cf. Fyfe, 1973; Powell, 1983). A provisional estimate of $1.98 \mathrm{~mol} \%$ was made for $\mathrm{H}_{2} \mathrm{O}$ using the wt.\% Loss On Ignition (LOI) of volatile species recorded by the XRF analysis.

\section{$P-T$ estimates from petrogenetic pseudosections}

Calculations of mineral equilibria were made in the system $\mathrm{MnO}-\mathrm{N}_{2} \mathrm{O}-\mathrm{CaO}-\mathrm{K}_{2} \mathrm{O}-\mathrm{FeO}-\mathrm{MgO}-\mathrm{Al}_{2} \mathrm{O}_{3}-\mathrm{SiO}_{2}-$ $\mathrm{H}_{2} \mathrm{O}-\mathrm{TiO}_{2}-\mathrm{Fe}_{2} \mathrm{O}_{3}$ (MnNCKFMASHTO) using the computer software THERMOCALC (Powell and Holland, 1988; Powell et al., 1998; upgrade 3.25) and the internally-consistent thermodynamic dataset of Holland and Powell (1998; update Nov. 2003). Phases considered were biotite, cordierite, garnet, ilmenite, K-feldspar, liquid (silicate melt), muscovite, plagioclase, quartz, rutile, sillimanite and spinel. The activity-composition $(a-x)$ relationships used for biotite and ilmenite follow White et al. (2005); garnet, Zeh and Holness (2003); spinel, White et al. (2002); muscovite, Coggon and Holland (2002); K-feldspar, plagioclase and liquid (melt), White et al. (2001), and; cordierite, Maher et al. (1997). 
Table 2. Bulk composition data for the metapelitic gneiss from Clemence Massif.

\begin{tabular}{lccccccccccccc}
\hline & $\mathrm{SiO}_{2}$ & $\mathrm{TiO}_{2}$ & $\mathrm{Al}_{2} \mathrm{O}_{3}$ & $\mathrm{Fe}_{2} \mathrm{O}_{3}$ & $\mathrm{FeO}$ & $\mathrm{MnO}$ & $\mathrm{MgO}$ & $\mathrm{CaO}$ & $\mathrm{Na}_{2} \mathrm{O}$ & $\mathrm{K}_{2} \mathrm{O}$ & $\mathrm{P}_{2} \mathrm{O}_{5}$ & LOI & Total \\
\hline $\begin{array}{l}\text { Petrographic } \\
\text { method* wt.\% }\end{array}$ & 54.80 & 1.65 & 24.25 & 0.26 & 11.66 & - & 2.76 & - & 0.61 & 4.01 & - & - & 100.00 \\
XRF wt.\% & 58.67 & 0.81 & 21.59 & 9.97 & - & 0.12 & 1.71 & 0.34 & 1.11 & 4.91 & 0.09 & 0.53 & 99.85 \\
XRF\& wt.\% & 58.76 & 0.81 & 21.62 & 0.22 & 9.75 & 0.12 & 1.71 & 0.34 & 1.11 & 4.92 & 0.09 & 0.53 & 100.00 \\
Average wt.\% & 56.78 & 1.23 & 22.94 & 0.24 & 10.70 & 0.12 & 2.24 & 0.34 & 0.86 & 4.46 & 0.09 & 0.53 & - \\
Mol.\% & 63.40 & 1.03 & 15.09 & 0.10 & 9.99 & 0.11 & 3.72 & 0.41 & 0.93 & 3.18 & 0.04 & 1.98 & - \\
BULK ROCK & 63.43 & 1.03 & 15.10 & 0.10 & 10.00 & 0.11 & 3.73 & 0.41 & 0.93 & 3.18 & - & 1.98 & 100.00 \\
\hline
\end{tabular}

*Major oxides calculated using mineral volume percentages after Friedman (1960). To estimate $\mathrm{Fe}_{2} \mathrm{O}_{3}$ content, we assumed realistic $\mathrm{Fe}^{3+} / \mathrm{Fe}^{\mathrm{T}}$ values of 0.08 for biotite, 0.05 for ilmenite and 0.00 for garnet in the calculation.

$\S \mathrm{XRF}$ data recalculated to $100 \%$ with iron distributed into ferric and ferrous oxides based on the petrographic derived ratio.

Figure 4 is a $P-T$ pseudosection depicting mineral equilibria appropriate for the bulk rock composition in Table 2, subsequent to major prograde dehydrationmelting reactions and melt loss events (cf. Thompson, 1982; White and Powell, 2002). In this model, the preserved assemblage of K-feldspar-garnet-quartzsillimanite-biotite-ilmenite-rutile is stable in a narrow pentavariant field from 8 to $9 \mathrm{kbar}$ and 760 to $790^{\circ} \mathrm{C}$. This pressure constraint is based largely on the position of the reaction boundary for rutile growth, which varies according to poorly known $\mathrm{Fe}_{2} \mathrm{O}_{3}$ content (Fig. 4). A more conservative $P$ estimate of $6-9 \mathrm{kbar}$, at say $775^{\circ} \mathrm{C}$, is made by considering the absence of cordierite and kyanite in the rock.

Figures $5 \mathrm{a}-5 \mathrm{~h}$ show mineral abundance isopleths (in mol. proportions) for each phase of concern over the relevant $P-T$ space. At the inferred equilibrium conditions (indicated by a star), the predicted mineral abundances are approximately equal to those actually observed in the rock (Table 1). For example, predicted/observed amounts for garnet are 30/33 mol.\%; K-feldspar, 28/26 mol.\%; quartz, 18/19 mol.\%; sillimanite, 13/16 mol.\%; liquid, 7/0 mol.\%; biotite, $2 / 3$ mol.\%; ilmenite, $2 / 2$ mol. $\%$, and; rutile $0.2 / 0.2$ mol.\%. According to the logic of Stüwe and Powell (1995), this result suggests that the preserved assemblage probably did not undergo any significant re-equilibration after crystallising at around $8-9 \mathrm{kbar}$ and $760-790^{\circ} \mathrm{C}$. Minor discrepancies between the observed and predicted amounts of each phase may be attributable to inaccuracies in the bulk composition, some of which could be a function of garnet fractionation from the system (cf. Stüwe, 1997). As a relevant example, Figure 6 shows a $T$ $X_{\mathrm{EBC}}$ pseudosection in which some almandine forming elements (mainly $\mathrm{Fe}$ ) are removed from the bulk chemistry, with a predicted increase in sillimanite abundance because of the effective increase in Al.

Interpretative $P-T$ paths for biotite, sillimanite and rutile growth are shown in Figures 5c, e and g, near to the inferred equilibration conditions. It is deduced that late biotite growth, albeit minor, must have proceeded along a cooling path. However, the predicted increase in biotite of up to 7 mol.\% during cooling from 790 to $760^{\circ} \mathrm{C}$

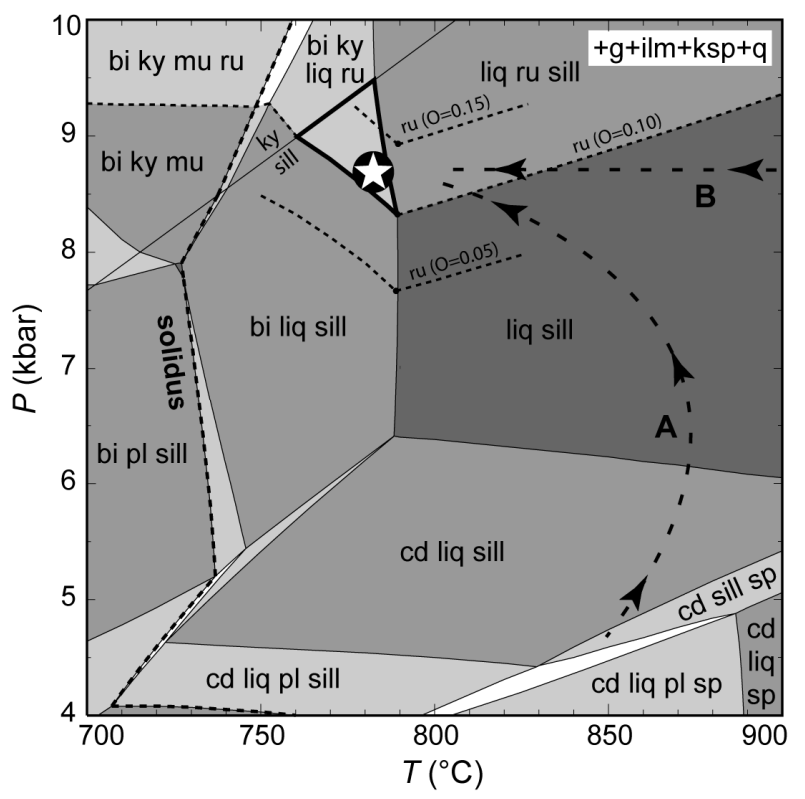

Figure 4. $P-T$ pseudosection in MnNCKFMASHTO for the bulk composition: $\mathrm{MnO}=0.11, \mathrm{Na}_{2} \mathrm{O}=0.93, \mathrm{Ca}=0.41$, $\mathrm{K}_{2} \mathrm{O}=3.18, \quad \mathrm{FeO}=10.01, \quad \mathrm{MgO}=3.72, \quad \mathrm{Al}_{2} \mathrm{O}_{3}=15.10$, $\mathrm{SiO}_{2}=63.43, \mathrm{H}_{2} \mathrm{O}=1.03, \mathrm{Fe}_{2} \mathrm{O}_{3}=0.10$. The assemblage of interest in this study is indicated by the star. Zero molar abundance isopleths for rutile are depicted for varying $\mathrm{Fe}_{2} \mathrm{O}_{3}$ values of $0.05 \mathrm{~mol} . \%, 0.10 \mathrm{~mol} . \%$ and $0.15 \mathrm{~mol} . \%$. The arrowed lines (labeled A and B) represent hypothetical $P-T$ paths on the basis of relic spinel inclusions in garnet, emanating from lower $P$ (path A) or substantially higher $T$ (path B). Mineral abbreviations: bi, biotite; cd, cordierite; g, garnet; ilm, ilmenite; ksp, Kfeldspar; ky, kyanite; liq, liquid; mu, muscovite; pl, plagioclase; q, quartz; ru, rutile; sill, sillimanite; sp, spinel. 
implies a greater amount of retrograde hydration than is observed in the rock, and that $\mathrm{H}_{2} \mathrm{O}$ content is slightly overestimated in our model. An overestimate of $\mathrm{H}_{2} \mathrm{O}$ also explains the predicted 7 mol.\% of a liquid phase (Fig. 5a), which does not necessarily signify congealed melt in situ (cf. Brown, 2002). Again, the very low amount of observed biotite ( $3 \mathrm{~mol} . \%)$ and lack of any evidence for substantial rehydration suggests that most melt migrated out of the equilibration volume considered in this study (Spear et al., 1999; White and Powell, 2002). The growth of sillimanite could reflect a former increase in $P$, in accord with the production of rutile. In addition, the microstructural evidence for continued growth of sillimanite relative to garnet (Fig. 5b) seems consistent with a component of cooling in the $P-T$ path.


Figure 5. Molar abundance isopleths for the relevant phases $(\mathrm{a}-\mathrm{h})$ shown on a portion of the $P-T$ pseudosection in Figure 4. The isopleth values at the star, appropriate to the observed assemblage, are: melt $=0.07$, garnet $=0.30$, biotite $=0.02$, K-felspar $=0.28$, sillimanite $=0.13$, ilmenite $=0.02$, rutile $=0.002$, and, quartz=0.18 q. Arrows in (c), (e) and (g) indicate $P-T$ paths over which biotite, sillimanite and rutile will grow in the vicinity of the observed assemblage. 


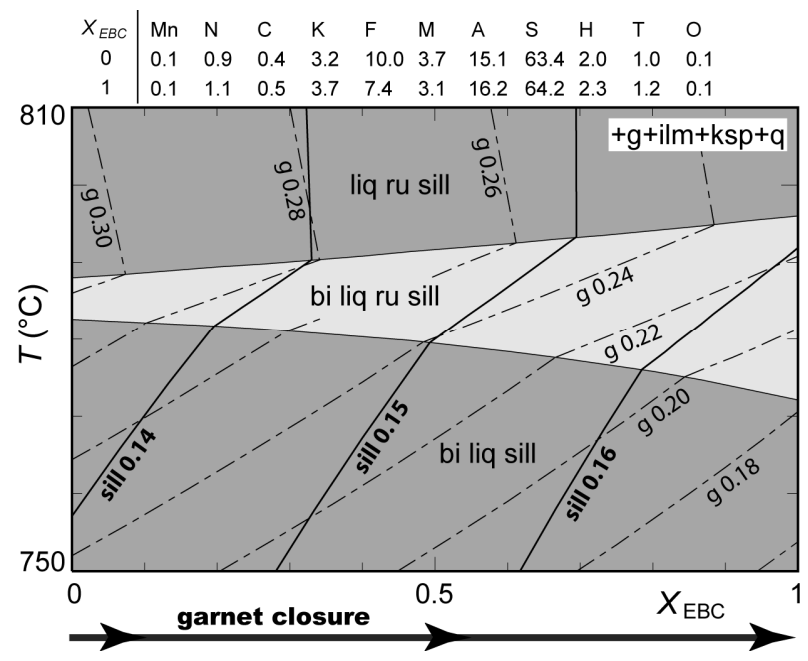

Figure 6. $T-X_{\mathrm{EBC}}$ pseudosection at $8.5 \mathrm{kbar}$ in the system MnNCKFMASHTO. $X_{\mathrm{EBC}}=0$ represents the bulk composition used in this study, whereas values of $X_{\mathrm{EBC}}$ between 0 and 1 reflect effective bulk compositions (EBC) that account for increasing garnet closure from the chemical system. Modal isopleths are shown for sillimanite (solid lines) and garnet (dashed lines). In this example, the proportion of sillimanite increases as a function of garnet closure.

\section{Discussion}

The estimated equilibration conditions of 8-9 kbar and $760-790^{\circ} \mathrm{C}$ for metapelitic gneiss from Clemence Massif are consistent with parts of the adjacent Amery Ice Shelf region and Northern PCM (Fig. 1). Most notably, they are comparable to conditions of $\sim 7-7.5$ kbar and $\sim 800^{\circ} \mathrm{C}$ recognised for Jetty Peninsula (Hand et al., 1994), and of $\sim 7-10 \mathrm{kbar}$ and $\sim 800-900^{\circ} \mathrm{C}$ for the Reinbolt Hills (Nichols and Berry, 1991; Ziemann et al., 2005). Additionally, metapelitic gneisses from these localities contain near-peak assemblages involving garnet-sillimanite-quartz-K-feldspar-ilmenite-rutile (plus biotite and plagioclase at Reinbolt Hills), that are similar to our sample from Clemence Massif (Nichols and Berry, 1991; Hand et al., 1994).

Another reason for comparing the metamorphism of Clemence Massif with Jetty Peninsula is that, to the best of our knowledge, they are the only localities within the PCM that show any evidence of a substantial $~ 500 \mathrm{Ma}$ thermal event overprinting Grenville-age rocks. Petrographically similar gneissose leucogranites (or leucogneisses) from each locality have yielded virtually identical U-Pb zircon ages of 940-910 Ma (Manton et al., 1992; Corvino et al., 2005) that reflect the timing of granulite-facies reworking in the adjoining Northern PCM (e.g. Kinny et al., 1997; Boger et al., 2000; Carson et al., 2000). However, the leucogranites were also affected by a thermal event at $\sim 500 \mathrm{Ma}$, as shown by lower intercept and concordant zircon ages (Manton et al., 1992; Corvino et al., 2005), that is not apparent in the Northern PCM.
Although the effect of a $\sim 500$ Ma thermal event on metapelitic gneisses from Jetty Peninsula could be indicated by the growth of secondary cordieritehercynite symplectites (Hand et al., 1994; Scrimgeour and Hand, 1997), such reaction microstructures are not evident in our sample. An important difference is that we observe hercynite as relic inclusions in garnet. The petrogenetic grids of, for example, Bohlen et al. (1986), Hensen (1986) and Clarke et al. (1989), suggest that this is most likely the result of an anticlockwise $P-T-t$ path. In which case, the metamorphic evolution of Clemence Massif might be better compared to parts of the Northern PCM further to the west of Jetty Peninsula, where metapelitic granulites reworked at $\sim 1000 \mathrm{Ma}$ also record anticlockwise $P-T$ paths (Thost and Hensen, 1992; Boger and White, 2003). Nonetheless, properly delineating an anticlockwise $P-T$ path for our sample is problematic because (i) reaction microstructures are generally lacking, and (ii) the primary hercynite may have been stable at substantially lower $T$, and higher $P$, owing to its Zn content (Nichols et al., 1992).

Relating the observations made here to the $\sim 1000$ Ma and $\sim 500$ Ma radiogenic ages for Clemence Massif is not straightforward (Tingey, 1991; Corvino et al., 2005). Perhaps the simplest interpretation is to consider that the relic spinel inclusions reflect the $\sim 1000 \mathrm{Ma}$ event, and that the assemblage of K-feldspar-garnetquartz-sillimanite-biotite-ilmenite-rutile equilibrated during the $\sim 500 \mathrm{Ma}$ event. However, if our particular rock was thoroughly dehydrated by melt loss during a $\sim 1000$ Ma granulite-facies event, then it may arguably record little microstructural evidence of a subsequent high-grade event at $500 \mathrm{Ma}$ (cf. White and Powell, 2002). The preserved assemblage could, therefore, be a $\sim 1000$ Ma product entirely. Another possibility is that the protolith of the metapelite has a Neoproterozoic depositional age, in which case the high-grade metamorphism would have occurred at $\sim 500 \mathrm{Ma}$.

Acknowledgements. This work is a result of the 2002-03 Prince Charles Mountains Expedition of Germany and Australia (PCMEGA), funded by the Australian Antarctic Division (AAD) and the German Federal Republic Geological Survey (Bundesanstalt für Geowissenschaften und Rohstoffe, BGR). The participants of the 2002-03 PCMEGA and ANARE are thanked for their logistic support and friendship in Antarctica. We express our thanks to Geoff Clarke and Chris Carson for constructive reviews that helped improve this manuscript. Paul Fitzgerald is thanked for his editorial handling. A.F.C. acknowledges the financial support of a Melbourne Research Scholarship provided by The University of Melbourne.

\section{References}

Boger, S. D., C. J. Carson, C. J. L. Wilson, and C. M. Fanning (2000), Neoproterozoic deformation in the Radok Lake region of the northern Prince Charles Mountains, east Antarctica; evidence for a single protracted orogenic event, Precambrian Research, 104, 1-24.

Boger, S. D., and R. W. White (2003), The metamorphic evolution of metapelitic granulites from Radok Lake, northern Prince Charles Mountains, east Anarctica; evidence for an anticlockwise $P-T$ path, Journal of Metamorphic Geology, 21, 285-298.

Bohlen, S. R., W. A. Dollase, and V. J. Wall (1986), Calibration and applications of spinel equilibria in the system $\mathrm{FeO}-\mathrm{Al}_{2} \mathrm{O}_{3}-\mathrm{SiO}_{2}$, Journal of Petrology, 27, 1143-1156. 
Brown, M. (2002), Retrograde processes in migmatites and granulites revised, Journal of Metamorphic Geology, 20, 25-40.

Carson, C. J., S. D. Boger, C. M. Fanning, C. J. L. Wilson and D. Thost (2000), SHRIMP U-Pb geochronology from Mt. Kirkby, northern Prince Charles Mountains, East Antarctica, Antarctic Science, $12,429-442$.

Carver, R. E. (1971), Procedures in Sedimentary Petrology, John Wiley and Sons Inc., New York, $653 \mathrm{p}$.

Cesare, B., S. Meli, and L. Nodari (2005), $\mathrm{Fe}^{3+}$ reduction during biotite melting in graphitic metapelites: another origin of $\mathrm{CO}_{2}$ in granulites, Contributions to Mineralogy and Petrology, 149, 129140.

Clarke, G. L., R. Powell, and M. Guiraud (1989), Low-pressure granuilte facies metapelitic assemblages and corona textures from MacRoberston Land, east Antarctica: the importance of $\mathrm{Fe}_{2} \mathrm{O}_{3}$ and $\mathrm{TiO}_{2}$ in accounting for spinel-bearing assemblages, Journal of Metamorphic Geology, 7, 323-335.

Coggon, R. and T. J. B. Holland (2002), Mixing properties of phengitic micas and revised garnet-phengite thermobarometers, Journal of Metamorphic Geology, 20, 683-696.

Corvino, A. F., S. D. Boger, C. J. L. Wilson, and I.C.W. Fitzsimons (2005), Geology and SHRIMP U-Pb zircon chronology of the Clemence Massif, Central Prince Charles Mountains, East Antarctica, Terra Antartica, 12, 55-68.

Deer, W. A., R. A. Howie, and J. Zussman (1992), An Introduction to the Rock Forming Minerals - 2nd ed, Pearson Education Limited, Harlow, England, 696 p.

Dyar, M.D., E.W. Lowe, C.V. Guidotti, and J. S. Delaney (2002), $\mathrm{Fe}^{3+}$ and $\mathrm{Fe}^{2+}$ partitioning among silicates in metapelites: A synchrotron micro-XANES study, American Mineralogist, 87, 514-522.

Friedman, G. M. (1960), Chemical analyses of rocks with the petrographic microscope, American Mineralogist, 45, 69-78.

Fyfe, W. S. (1973), The Granulite Facies, Partial Melting and the Archaean Crust, Philosophical Transactions for the Royal Society of London. Series, A273, 457-461.

Guidotti, C. V., and M. D. Dyar (1991), Ferric iron in metamorphic biotite and its petrologic and crystallochemical implications, American Mineralogist, 76, 161-175.

Hand, M., I. Scrimgeour, R. Powell, K. Stüwe, and C. J. L. Wilson (1994), Metapelitic granulites from Jetty Peninsula, east Antarctica: formation during a single event or by polymetamorphism?, Journal of Metamorphic Geology, 12, 557-573.

Hensen, B. J. (1986), Theoretical phase relations involving cordierite and garnet revisited: the influence of oxygen fugacity on the stability of sapphirine and spinel in the system $\mathrm{Mg}-\mathrm{Fe}-\mathrm{Al}-\mathrm{Si}-\mathrm{O}$, Contributions to Mineralogy and Petrology, 92, 362-367.

Holland, T. J. B., and R. Powell (1998), An internally consistent thermodynamic data set for phases of petrological interest, Journal of Metamorphic Geology, 16, 309-343.

Johnson, S. E., and R. H. Vernon (1995), Inferring the timing of porphyroblast growth in the absence of continuity between inclusion trails and matrix foliations: can it be reliably done?, Journal of Structural Geology, 17, 1203-1206.

Kinny, P. D., L. P. Black, and J. W. Sheraton (1997), Zircon U-Pb ages and geochemistry of igneous and metamorphic rocks in the northern Prince Charles Mountains, AGSO Journal of Australian Geology \& Geophysics, 16, 637-654.

Krynauw, J. R. (1996), A review of the geology of East Antarctica, with special reference to the c. $1000 \mathrm{Ma}$ and c. $500 \mathrm{Ma}$ events, Terra Antartica, 3, 77-89.

Manton, W. I., E. S. Grew, J. Hofmann, and J. W. Sheraton (1992), Granitic rocks of the Jetty Peninsula, Amery Ice Shelf area, East Antarctica, in Recent Progress in Antarctic Earth Science, edited by Yoshida, Y., K. Kaminuma, and K. Shiraishi, Terra Scientific Publishing Company, Tokyo, 179-189.

Mahar, E. M., J. M. Baker, R. Powell, T. J. B. Holland, and N. Howell (1997), The effect of Mn on mineral stability in metapelites, Journal of Metamorphic Geology, 15, 223-238.

McLeod, I. R., (1959), Report on geological and glaciological work by the 1958 Australian National Antarctic Research Expedition, Bureau of Mineral Resources Australia, Record 1959/131.
Mikhalsky, E. V., J. W. Sheraton, A. A. Laiba, R. J. Tingey, D. E. Thost, E. N. Kamenev, and L. V. Fedorov (2001), Geology of the Prince Charles Mountains, Antarctica, AGSO - Geoscience Australia, Canberra, bulletin 247.

Nichols, G. T., and R. F. Berry (1991), A decompressional $P-T$ path, Reinbolt Hills, East Antarctica, Journal of Metamorphic Geology, 9, 257-266.

Nichols, G. T., R. F. Berry, and D. H. Green (1992), Internally consistent gahnitic spinel-cordierite-garnet equilibria in the FMASHZn system: geothermobarometry and applications, Contributions to Mineralogy and Petrology, 111, 362-377.

Powell, R. (1983), Processes in Granulite-facies Metamorphism, in Migmatites, Melting and Metamorphism, edited by Atherton, M. P., and C. D. Gribble, Shiva, Nantwich, United Kingdom, 127-139.

Powell, R., and T. J. B. Holland (1988), An internally consistent thermodynamic dataset with uncertainties and correlations: 3 . Application methods, worked examples and a computer program, Journal of Metamorphic Geology, 6, 173-204.

Powell, R., T. Holland, and B. Worley (1998), Calculating phase diagrams involving solid solutions via non-linear equations, with examples using THEMOCALC, Journal of Metamorphic Geology, $16,577-588$

Scrimgeour, I., and M. Hand (1997), A metamorphic perspective on the Pan-African overprint in the Amery area of Mac. Robertson Land, East Antarctica, Antarctic Science, 9, 313-335.

Shau, Y., H. Yang, and D. R. Peacor (1991), On oriented titanite and rutile inclusions in sagentic biotite, American Mineralogist, 76, $1205-1217$.

Sheraton, J. (1980), Geochemistry of Precambrian metapelites from East Antarctica: secular and metamorphic variations, BMR Journal of Australian Geology and Geophysics, 5, 279-288.

Spear, F. S., M. J. Kohn, and J. T. Cheney (1999), $P-T$ paths from anatectic pelites, Contributions to Mineralogy and Petrology, 134, $17-32$.

Stüwe, K., and R. Powell (1995), PT paths from modal proportions: applications to the Koralm Complex, Eastern Alps, Contributions to Mineralogy and Petrology, 119, 83-93.

Stüwe, K (1997), Effective bulk composition changes due to cooling: a model predicting complexities in retrograde reaction textures, Contributions to Mineralogy an Petrology, 129, 43-52.

Thompson, A. B. (1982), Dehydration melting of pelitic rocks and the generation of $\mathrm{H}_{2} \mathrm{O}$-undersaturated granitic liquids, American Journal of Science, 282, 1567-1595.

Thost, D. E., and B. J. Hensen (1992), Gneisses of the Porthos and Athos Ranges, Northern Prince Charles Mountains, East Anarctica: Constraints on the prograde and retrograde $P-T$ path, in Recent Progress in Antarctic Earth Science, edited by Yoshida, Y., K. Kaminuma, and K. Shiraishi, Terra Scientific Publishing Company, Tokyo, 93-102.

Tingey, R. J., R. N. England, and J. W. Sheraton (1981), Geological investigations in Antarctica 1973 - the southern Prince Charles Mountains, Bureau of Mineral Resources Australia, Record $1981 / 43$.

White, R. W., and R. Powell (2002), Melt loss and the preservation of granulite facies mineral assemblages, Journal of Metamorphic Geology, 20, 621-632.

White, R. W., R. Powell, and T. J. B. Holland (2001), Calculation of partial melting equilibria in the system $\mathrm{Na}_{2} \mathrm{O}-\mathrm{CaO}-\mathrm{K}_{2} \mathrm{O}-\mathrm{FeO}-$ $\mathrm{MgO}-\mathrm{Al}_{2} \mathrm{O}_{3}-\mathrm{SiO}_{2}-\mathrm{H}_{2} \mathrm{O}$ (NCKFMASH), Journal of Metamorphic Geology, 19, 139-153

White, R. W., R. Powell, and G. L. Clarke (2002), The interpretation of reaction textures in Fe-rich metapelitic granulites of the Musgrave Block, central Australia: constraints from mineral equilibria calculations in the system $\mathrm{K}_{2} \mathrm{O}-\mathrm{FeO}-\mathrm{MgO}-\mathrm{Al}_{2} \mathrm{O}_{3}-\mathrm{SiO}_{2}-$ $\mathrm{H}_{2} \mathrm{O}-\mathrm{TiO}_{2}-\mathrm{Fe}_{2} \mathrm{O}_{3}$, Journal of Metamorphic Geology, 20, 41-55.

White, R. W., N. E. Pomroy, and R. Powell (2005), An in situ metatexite-diatexite transition in upper amphibolite facies rocks from Broken Hill, Australia, Journal of Metamorphic Geology, 23, 579-602.

Yoshida, M., J. Jacobs, M. Santosh, and H. M. Rajesh (2003), Role of Pan-African events in the Circum-East Antarctic Orogen of East Gondwana: a critical overview, in Proterozoic East Gondwana: 
Supercontinent Assembly and Breakup, edited by Yoshida M., B. F. Windley, and S. Dasgupta, Geological Society, London, Special Publications, 206, 57-75.

Ziemann, M. A., H-J. Förster, D. E. Harlov, and D. Frei (2005), Origin of fluorapatite-monazite assemblages in a metamorphosed, sillimanite-bearing pegmatoid, Reinbolt Hills, East Antarctica, European Journal of Mineralogy, 17, 567-579.

Zeh, A. and M. B. Holness (2003), The effect of reaction overstep on garnet microtextures in metapelitic rocks of the Ilesha Schist Belt, SW Nigeria, Journal of Petrology, 44, 967-994.

\section{Appendix A. Mineral properties table}

Table A1. Listing of some mineral properties used in this study. All data is from Holland and Powell (1998), except specific gravity values which are taken from Deer et al. (1992). The effective volumes for garnet and biotite are the averaged molar volumes for the different end-members of those minerals (following Stüwe and Powell, 1995).

\begin{tabular}{lllllll}
\hline Mineral & Formula & Symbol & $\begin{array}{l}\text { Specific } \\
\text { gravity }\end{array}$ & $\begin{array}{l}\text { Volume J } \\
\text { bar }\end{array}$ & $\begin{array}{l}\text { Effective } \\
\text { volume }\end{array}$ & $\begin{array}{l}\text { No. of } \\
\text { oxides }\end{array}$ \\
\hline $\begin{array}{l}\text { K-feldspar } \\
\text { Quartz }\end{array}$ & $\mathrm{KAlSi}_{3} \mathrm{O}_{8}$ & $\mathrm{ksp}$ & 2.6 & 10.900 & 10.900 & 4 \\
Garnet & & $\mathrm{q}$ & 2.7 & 2.269 & 2.269 & 1 \\
Almandine & $\mathrm{Fe}_{3} \mathrm{Al}_{2} \mathrm{Si}_{3} \mathrm{O}_{12}$ & $\mathrm{~g}$ & 4.0 & & 11.435 & 7 \\
Pyrope & $\mathrm{Mg}_{3} \mathrm{Al}_{2} \mathrm{Si}_{3} \mathrm{O}_{12}$ & alm & & 11.551 & & \\
Sillimanite & $\mathrm{Al}_{2} \mathrm{SiO}_{5}$ & sill & & 11.318 & & \\
Biotite & & bi & 3.0 & 4.986 & 4.986 & 2 \\
Annite & $\mathrm{KFe}_{3} \mathrm{AlSi}_{3} \mathrm{O}_{10}(\mathrm{OH})_{2}$ & ann & & 15.432 & & 7 \\
Phlogopite & $\mathrm{KMg}_{3} \mathrm{AlSi}_{3} \mathrm{O}_{10}(\mathrm{OH})_{2}$ & phl & & 14.964 & & \\
Ilmenite & $\mathrm{FeTiO}_{3}$ & ilm & 4.7 & 3.169 & 3.169 & 2 \\
Rutile & $\mathrm{TiO}_{2}$ & ru & 4.8 & 1.882 & 1.882 & 1 \\
\hline
\end{tabular}

\section{Appendix B. Mineral chemistry tables}

Table B1. Chemical analyses of garnet (g) and biotite (bi). $X_{\mathrm{Mg}}=\mathrm{Mg} /\left(\mathrm{Fe}^{\mathrm{T}}+\mathrm{Mg}\right.$ ). Coexisting mineral pairs are included in square brackets.

\begin{tabular}{|c|c|c|c|c|c|c|c|c|c|c|c|c|}
\hline & g1 core & g1 rim & g2 core & g3[ilm2] & $\mathrm{g} 4[\mathrm{bi} 2]$ & g5 & g6 & bi1 & bi2[g4] & bi3 & bi4 & bi5 \\
\hline $\mathrm{SiO}_{2}$ & 38.44 & 38.39 & 37.59 & 36.45 & 37.40 & 37.43 & 37.55 & 35.72 & 35.67 & 35.08 & 37.59 & 37.44 \\
\hline $\mathrm{TiO}_{2}$ & 0.02 & 0.03 & 0.04 & 0.05 & 0.04 & 0.03 & 0.01 & 6.34 & 5.55 & 4.58 & 3.60 & 3.38 \\
\hline $\mathrm{Al}_{2} \mathrm{O}_{3}$ & 21.55 & 21.61 & 21.66 & 21.47 & 21.46 & 21.71 & 21.69 & 16.80 & 16.25 & 15.81 & 17.34 & 16.84 \\
\hline $\mathrm{Cr}_{2} \mathrm{O}_{3}$ & 0.00 & 0.05 & 0.05 & 0.02 & 0.09 & 0.06 & 0.02 & 0.14 & 0.13 & 0.20 & 0.13 & 0.15 \\
\hline $\mathrm{FeO}^{\mathrm{T}}$ & 32.56 & 32.30 & 33.01 & 32.75 & 33.22 & 33.07 & 33.14 & 18.03 & 17.56 & 16.26 & 13.22 & 11.66 \\
\hline $\mathrm{MnO}$ & 0.51 & 0.54 & 0.54 & 0.54 & 0.56 & 0.56 & 0.56 & 0.01 & 0.01 & 0.02 & 0.00 & 0.00 \\
\hline $\mathrm{MgO}$ & 6.59 & 6.52 & 6.30 & 6.46 & 6.06 & 6.38 & 6.31 & 10.86 & 10.69 & 12.87 & 15.33 & 17.45 \\
\hline $\mathrm{CaO}$ & 1.06 & 1.04 & 1.14 & 1.13 & 1.13 & 1.15 & 1.15 & 0.00 & 0.00 & 0.00 & 0.00 & 0.02 \\
\hline $\mathrm{Na}_{2} \mathrm{O}$ & 0.07 & 0.06 & 0.01 & 0.02 & 0.03 & 0.05 & 0.04 & 0.18 & 0.14 & 0.11 & 0.12 & 0.15 \\
\hline $\mathrm{K}_{2} \mathrm{O}$ & 0.01 & 0.00 & 0.02 & 0.01 & 0.03 & 0.00 & 0.02 & 9.24 & 9.31 & 8.93 & 9.01 & 9.65 \\
\hline $\mathrm{ZnO}$ & 0.07 & 0.00 & 0.06 & 0.02 & 0.03 & 0.07 & 0.00 & 0.01 & 0.13 & 0.00 & 0.00 & 0.08 \\
\hline Total & 100.87 & 100.53 & 100.42 & 98.92 & 100.04 & 100.49 & 100.48 & 97.36 & 95.44 & 93.86 & 96.36 & 96.82 \\
\hline & \multicolumn{7}{|c|}{$24 \mathrm{O}$ apfu } & \multicolumn{5}{|c|}{$22 \mathrm{O}$ apfu } \\
\hline $\mathrm{Si}$ & 6.00 & 6.00 & 5.92 & 5.84 & 5.93 & 5.90 & 5.92 & 5.30 & 5.40 & 5.37 & 5.47 & 5.42 \\
\hline $\mathrm{Ti}$ & 0.00 & 0.00 & 0.00 & 0.01 & 0.00 & 0.00 & 0.00 & 0.71 & 0.63 & 0.53 & 0.39 & 0.37 \\
\hline $\mathrm{Al}$ & 3.97 & 3.98 & 4.02 & 4.06 & 4.01 & 4.03 & 4.03 & 2.94 & 2.90 & 2.85 & 2.97 & 2.87 \\
\hline $\mathrm{Cr}$ & 0.00 & 0.01 & 0.01 & 0.00 & 0.01 & 0.01 & 0.00 & 0.02 & 0.02 & 0.02 & 0.01 & 0.02 \\
\hline $\mathrm{Fe}^{\mathrm{T}}$ & 4.25 & 4.23 & 4.35 & 4.39 & 4.40 & 4.36 & 4.37 & 2.24 & 2.22 & 2.08 & 1.61 & 1.41 \\
\hline $\mathrm{Mn}$ & 0.07 & 0.07 & 0.07 & 0.07 & 0.07 & 0.07 & 0.08 & 0.00 & 0.00 & 0.00 & 0.00 & 0.00 \\
\hline $\mathrm{Mg}$ & 1.53 & 1.52 & 1.48 & 1.54 & 1.43 & 1.50 & 1.48 & 2.40 & 2.41 & 2.93 & 3.33 & 3.76 \\
\hline $\mathrm{Ca}$ & 0.18 & 0.17 & 0.19 & 0.19 & 0.19 & 0.19 & 0.19 & 0.00 & 0.00 & 0.00 & 0.00 & 0.00 \\
\hline $\mathrm{Na}$ & 0.02 & 0.02 & 0.00 & 0.01 & 0.01 & 0.01 & 0.01 & 0.05 & 0.04 & 0.03 & 0.03 & 0.04 \\
\hline K & 0.00 & 0.00 & 0.00 & 0.00 & 0.01 & 0.00 & 0.00 & 1.75 & 1.80 & 1.74 & 1.67 & 1.78 \\
\hline $\mathrm{Zn}$ & 0.01 & 0.00 & 0.01 & 0.00 & 0.00 & 0.01 & 0.00 & 0.00 & 0.01 & 0.00 & 0.00 & 0.01 \\
\hline Total & 16.03 & 16.01 & 16.06 & 16.12 & 16.07 & 16.09 & 16.08 & 15.41 & 15.43 & 15.56 & 15.49 & 15.68 \\
\hline$X_{\mathrm{Mg}}$ & 0.27 & 0.26 & 0.25 & 0.26 & 0.25 & 0.26 & 0.25 & 0.52 & 0.52 & 0.59 & 0.67 & 0.73 \\
\hline
\end{tabular}


Table B2. Chemical analyses of K-feldspar (ksp), ilmenite (ilm), rutile (ru) and spinel (sp). Coexisting mineral pairs are included in square brackets.

\begin{tabular}{llllllllll}
\hline & ksp1 & ksp2 & ksp3 & ilm1 & ilm2[g3] & ru1 & ru2 & sp1 & sp2 \\
\hline $\mathrm{SiO}_{2}$ & 64.68 & 65.02 & 67.19 & 0.00 & 0.00 & 0.00 & 0.00 & 0.00 & 0.00 \\
$\mathrm{TiO}_{2}$ & 0.02 & 0.03 & 0.04 & 53.21 & 52.98 & 97.03 & 94.73 & 0.02 & 0.00 \\
$\mathrm{Al}_{2} \mathrm{O}_{3}$ & 19.20 & 19.31 & 19.29 & 0.00 & 0.02 & 0.10 & 0.09 & 57.87 & 58.29 \\
$\mathrm{Cr}_{2} \mathrm{O}_{3}$ & 0.00 & 0.02 & 0.00 & 0.04 & 0.02 & 0.04 & 0.14 & 0.67 & 0.55 \\
$\mathrm{FeO}^{\mathrm{T}}$ & 0.00 & 0.00 & 0.00 & 47.07 & 45.40 & 0.47 & 0.90 & 21.58 & 23.24 \\
$\mathrm{MnO}$ & 0.00 & 0.00 & 0.03 & 0.23 & 0.19 & 0.03 & 0.02 & 0.02 & 0.01 \\
$\mathrm{MgO}$ & 0.02 & 0.00 & 0.00 & 0.05 & 0.32 & 0.01 & 0.01 & 6.41 & 6.44 \\
$\mathrm{CaO}$ & 0.12 & 0.10 & 0.11 & 0.00 & 0.00 & 0.02 & 0.01 & 0.00 & 0.01 \\
$\mathrm{Na} 2 \mathrm{O}$ & 1.99 & 1.98 & 1.79 & 0.00 & 0.01 & 0.03 & 0.03 & 0.41 & 0.36 \\
$\mathrm{~K} 2 \mathrm{O}$ & 13.44 & 13.42 & 14.10 & 0.00 & 0.01 & 0.01 & 0.01 & 0.01 & 0.01 \\
$\mathrm{ZnO}$ & 0.00 & 0.02 & 0.00 & 0.05 & 0.00 & 0.00 & 0.00 & 10.20 & 9.04 \\
\hline $\mathrm{Total}$ & 99.89 & 99.89 & 102.56 & 100.67 & 98.95 & 97.73 & 95.93 & 97.20 & 97.97 \\
\hline & & $32 \mathrm{O}$ apfu & & 6 & $0 a p f u$ & 2 & $\mathrm{O}$ \\
$\mathrm{Si}$ & 11.90 & 11.90 & 11.98 & 0.00 & 0.00 & 0.00 & 0.00 & 0.00 & 0.00 \\
$\mathrm{Ti}$ & 0.00 & 0.00 & 0.00 & 2.00 & 2.02 & 1.00 & 0.99 & 0.00 & 0.00 \\
$\mathrm{Al}$ & 4.16 & 4.16 & 4.05 & 0.00 & 0.00 & 0.00 & 0.00 & 15.74 & 15.72 \\
$\mathrm{Cr}$ & 0.00 & 0.00 & 0.00 & 0.00 & 0.00 & 0.00 & 0.00 & 0.12 & 0.10 \\
$\mathrm{Fe}$ & 0.00 & 0.00 & 0.00 & 1.97 & 1.92 & 0.01 & 0.01 & 4.16 & 4.45 \\
$\mathrm{Mn}$ & 0.00 & 0.00 & 0.00 & 0.01 & 0.01 & 0.00 & 0.00 & 0.00 & 0.00 \\
$\mathrm{Mg}$ & 0.01 & 0.00 & 0.00 & 0.00 & 0.02 & 0.00 & 0.00 & 2.20 & 2.20 \\
$\mathrm{Ca}$ & 0.02 & 0.02 & 0.02 & 0.00 & 0.00 & 0.00 & 0.00 & 0.00 & 0.00 \\
$\mathrm{Na}$ & 0.71 & 0.70 & 0.62 & 0.00 & 0.00 & 0.00 & 0.00 & 0.18 & 0.16 \\
$\mathrm{~K}$ & 3.15 & 3.13 & 3.21 & 0.00 & 0.00 & 0.00 & 0.00 & 0.00 & 0.00 \\
$\mathrm{Zn}$ & 0.00 & 0.00 & 0.00 & 0.00 & 0.00 & 0.00 & 0.00 & 1.74 & 1.53 \\
\hline $\mathrm{Total}$ & 19.95 & 19.93 & 19.90 & 3.99 & 3.98 & 1.00 & 1.00 & 24.15 & 24.16 \\
\hline
\end{tabular}

Note: Compositions were obtained using a CAMECA SX-50 Electron Probe Microanalyser (operating conditions 15 $\mathrm{kV}$ and $25 \mathrm{nA}$ probe current) at the School of Earth Sciences, The University of Melbourne, Australia. 